\title{
Central bank reserves during the Bretton Woods period: new data from France, the UK and Switzerland
}

\author{
Alain Naef ${ }^{1}$
}

January 18, 2021

\begin{abstract}
This paper presents new daily data on central bank reserves during the Bretton Woods period. It is the first paper to provide daily data for the Bank of France, Bank of England and Swiss National Bank directly from these central bank's archives. I discuss some of the issue with these data and make them available to other researchers for further analysis.
\end{abstract}

Keywords: foreign exchange reserves, central banks, Bretton Woods.

\footnotetext{
${ }^{1}$ Macroeconomist, Banque de France, alain.naef@banque-france.fr. The views expressed in this paper do not represent the opinion of the Banque de France or the Eurosystem. Data presented here come from publicly available sources and not the Banque de France. Part of this research was supported by the Economic and Social Research Council (grant number ESRC KFW/10324121/0) in 2014-19 as well as the Swiss National Science Foundation (grant number P2SKP1_181320) in 2019-20.
} 
This paper presents new reserve data from the UK, France and Switzerland at a daily frequency during the Bretton Woods period (1944-1972). The data have been collected from the archives of the Bank of England, Bank of France and Swiss National Bank and offer a daily overview of their main reserves in dollar and gold.

The main contribution is to offer daily data, which is made possible here because the data have been copied from previously confidential and now declassified data sources. Daily data where never made public and offer a granular view of the reserve position of these central banks. Another contribution of this paper is to make the data available for further analysis. ${ }^{2}$

A whole research agenda has looked into reserves during the Bretton Woods period to understand the relative position of the two main leading reserve currencies, the dollar and sterling. Eichengreen and Flandreau (2009) show that as early as the mid-1920s the dollar overtook sterling as a leading reserve currency, contrary to what was assumed in previous accounts; however, the two currencies kept fighting for leadership during the interwar years. ${ }^{3}$ Overall there is a consensus that the dollar was the leading reserve and international currency of the world in the Bretton Woods period. It is less clear what role sterling played. Avaro (2020b; 2020a) showed that the role of sterling was mainly one of legacy and that sterling was essentially a zombie

2 The data is available on the repository openICPSR on the following address https://www.openicpsr.org/openicpsr/project/130681/version/V1/view,

${ }^{3}$ Chiţu, Eichengreen, and Mehl (2014) also provide a further analysis of reserve currencies in a longer perspective. 
international reserve currency. Schenk (2011), on the other hand, has shown that in terms of composition of central bank reserves, sterling was still the most important currency until 1955. Schenk (2010) shows that sterling was not only used by loyal members of the Commonwealth but also countries like Iraq and Kuwait who kept sterling reserves, despite not being members of the Commonwealth.

Monnet and Puy (2020) also present new reserve data from the Bretton Woods period available online. ${ }^{4}$ Their data is however not coming directly from central banks archives but from IMF secondary sources and is at yearly and not daily frequency. Scholar interested in running a panel of multiple countries might find their dataset more useful, despite the lower frequency. And other data services (such as Global Financial Data) offer partial reserve data, but not at daily frequency for this or any other period.

This paper contributes to the literature by offering daily reserve data for France, the United Kingdom and Switzerland at a daily frequency for the Bretton Woods period.

\section{Data sources}

I present new previously unpublished daily data. Below I give the exact source of the data for each country. Table 1 offers a synthetic overview of the data.

\footnotetext{
${ }^{4}$ The data is available here https://didomena.ehess.fr/concern/data sets/w66344260?locale $=\mathrm{fr}$ when downloading the file labelled BrettonWoods MonnetPuy.xls
} 


\section{Table 1 - Overview of available data}

\begin{tabular}{l|lrrrrrr}
\multicolumn{1}{c}{ Central bank } & \multicolumn{1}{c}{ Reserve qualification } & Frequency & Timeframe & Gold & USD & $\begin{array}{c}\text { Other } \\
\text { data }\end{array}$ & $\begin{array}{c}\text { Counterparty } \\
\text { bank }\end{array}$ \\
\hline $\begin{array}{l}\text { Bank of England } \\
\text { Swiss National }\end{array}$ & Exchange Equalisation Account (EEA) & daily & $1947-71$ & Yes & Yes & No & No \\
$\begin{array}{l}\text { Bank } \\
\text { Bank of France }\end{array}$ & Aggregate for Switzerland & daily & $1941-67$ & Yes & Yes & No & No \\
& Fond de Stabilisation des Changes (FSC) & Monthly & $1949-70$ & Yes & Yes & Yes & Yes
\end{tabular}

The data on Bank of England reserves comes from the Exchange Equalization Account (EEA) ledgers (for more on the EEA, see (Howson 1980; Bank of England 1968; Naef 2020). The EEA is the British government's official reserve account. It has the particularity that while it is managed by the Bank of England, it belongs to the Treasury and hence the government. Data span 1947 to 1971. The data are collected directly from the Ledgers of the EEA (Bank of England archives, reference 2A141/1, ledgers 1 to 17). Note that these data represent the majority of UK reserves, but not all reserves, as the Bank of England also had (and still has) some very limited reserves. Naef (2020) also presents the dollar account for these data to illustrate window dressing.

The data for the Swiss National Bank come from the statistics office and offer daily data for all the country's reserves. They do not come from directly from ledgers (as is the case for the two other central banks analysed here), but from sources compiled by the Swiss National Bank's statistical office. The data span from 1942 to 1967 when the statistical office no longer register the data. They are available in manuscript files at the Swiss National Bank under reference 9.1/9106 Statistics. 
The data from the Bank of France are data for the Fond de Stabilisation des Changes (FSC). Just like for the British EEA, the FSC was specially put in place for reserve management. And because of this special legal structure, some of the data in the account is more difficult to interpret. The data come from ledgers and are extremely granular. They show the holdings of the FSC with private commercial banks in the UK and the US among other countries as well as account with other central banks. The ledgers of the FSC offer over 100 different labels as can be seen in Appendix B. They also show negative values at time which would need to be investigated further. They span 1949 to 1970. All the data were copied at the currency in which they were reported, and for comparability, they would have to be converted into USD or French francs. While the data from the Bank of England and Swiss National Bank can be used "as is" in further analysis, this data would need further processing and research.

Because of this complexity, data have only been copied monthly to give an overview, but at the archive of the Bank of France, reserves are available at daily frequency for interested researchers (Archives of the Bank of France, reference 1463200401-70 to 1463200401100, "Fond de stabilisation des changes livres de comptes"). 


\section{Data overview}

Figure 1 and 2 show the reserve data of the Exchange Equalisation Account and the Swiss National Bank. The variations in UK reserves show the various crises of the pound such as the 1949 devaluation (first dip) or the 1967 devaluation followed by a period of instability. In contrast, the Swiss National Bank went through a period of reserves accumulation and tried to avoid any large dollar balances. The Bank of England on the other hand relied on dollar funding with loans from the IMF or swap contracts with the New York Fed.

Figure 1 - Exchange Equalisation Account daily gold and dollar reserves

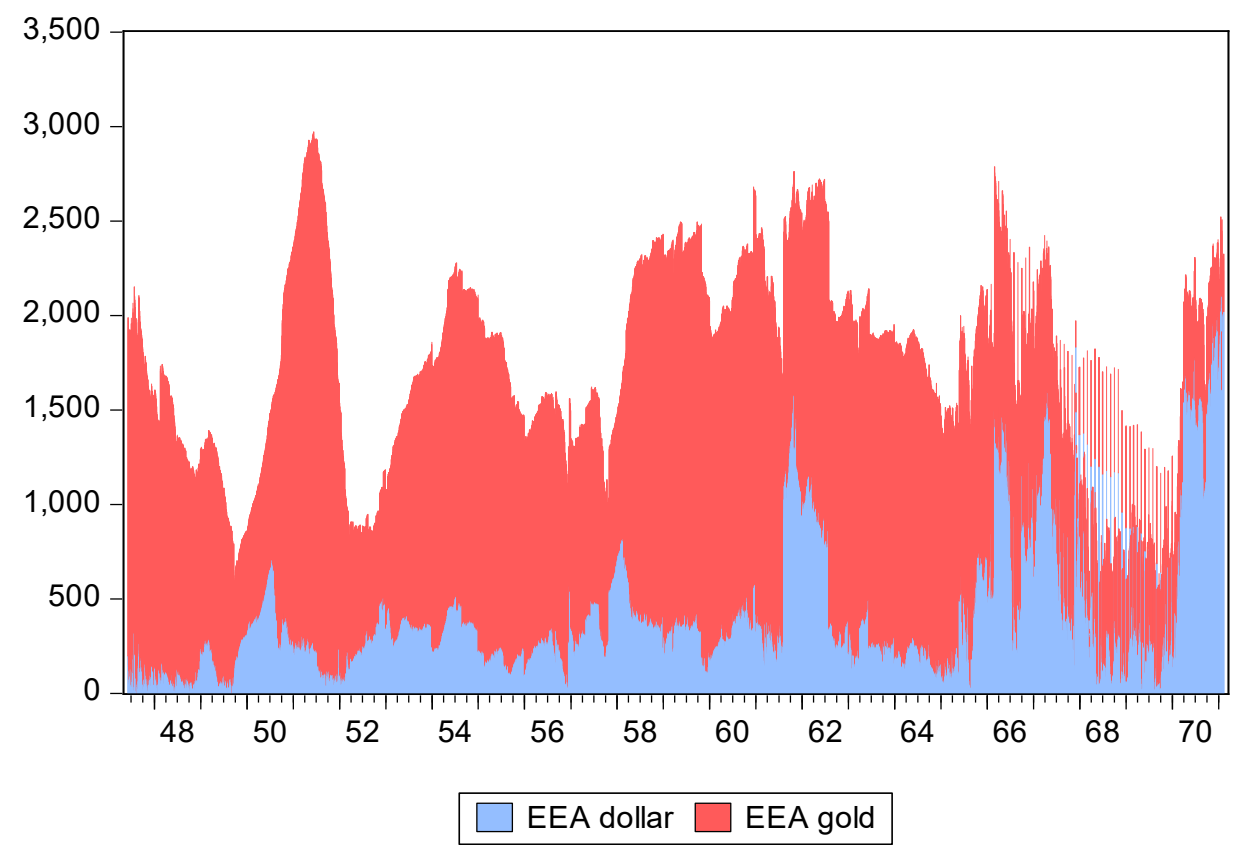


Figure 2 - Swiss National Bank daily gold and dollar reserves

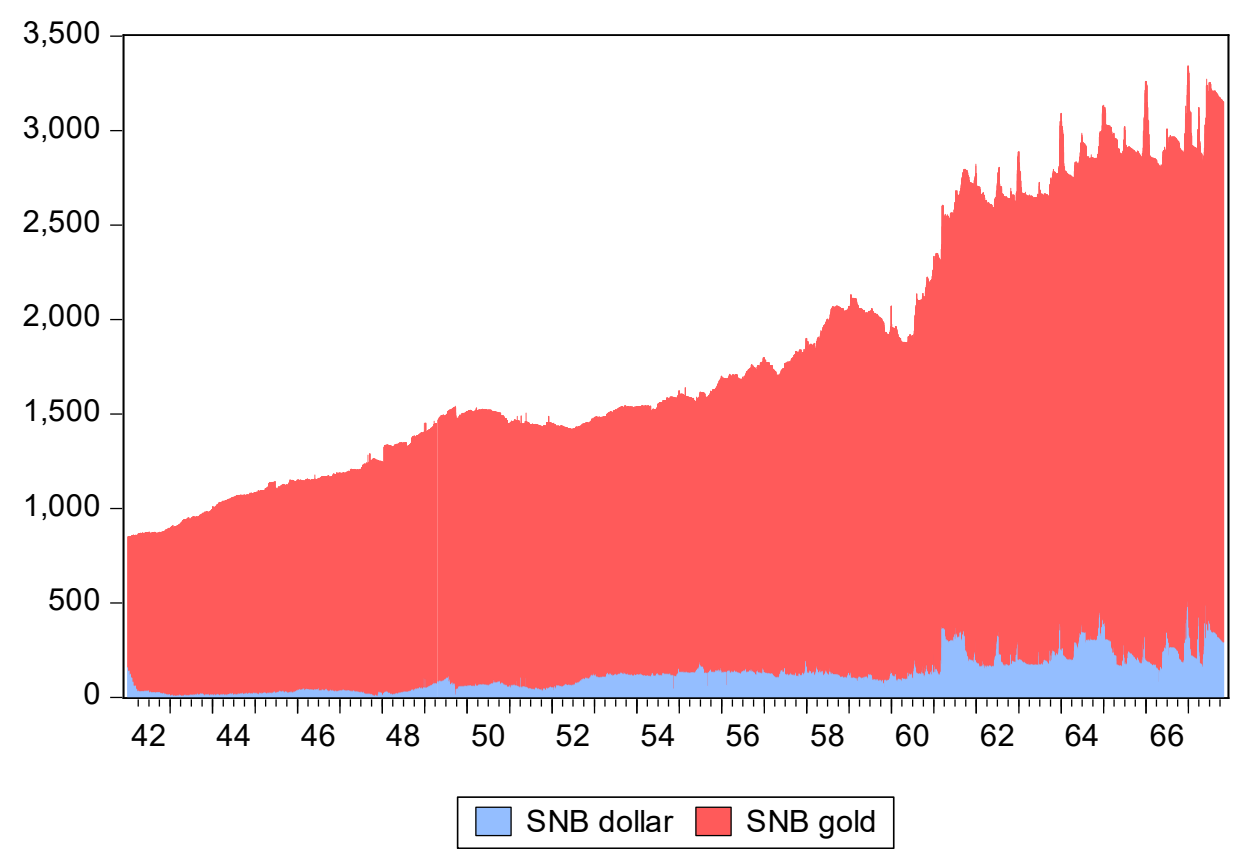

\section{Data processing for British reserves data}

British reserves were "window dressed" or manipulated before publication with short term swap borrowing at the end of each month to present higher reserves (for more details on this, see (Naef 2020; 2019). While this is an interesting historical fact, it introduces biases when using the data in statistical analysis. Therefore, I generated a dummy for window dressing to exclude these data from the analysis. This allows researchers to exclude this data in regression analysis. Below in Table 2 is an illustration on how the dummy is created, for each day when the reserves were artificially increased for reporting purposes (at the end of the month), the values are flagged as window dressed values. These should be discounted when trying to establish a true picture of reserves net of swap contracts. 
Table 2 - window dressing dummy example

EEA dollar reserves

\begin{tabular}{cccc} 
& $\begin{array}{c}\text { EEA dollar reserves } \\
\text { (as reported in } \\
\text { ledgers })\end{array}$ & Daily change & $\begin{array}{c}\text { Dummy for window } \\
\text { dressing }\end{array}$ \\
\hline $8 / 25 / 1969$ & 118 & -17 & 0 \\
$8 / 26 / 1969$ & 96 & -23 & 0 \\
$8 / 27 / 1969$ & 80 & -16 & 0 \\
$8 / 28 / 1969$ & 70 & -9 & 0 \\
$8 / 29 / 1969$ & 685 & 614 & 1 \\
$8 / 30 / 1969$ & 685 & 0 & 1 \\
$9 / 1 / 1969$ & 685 & 0 & 1 \\
$9 / 2 / 1969$ & 37 & -648 & 0 \\
$9 / 3 / 1969$ & 35 & -2 & 0 \\
$9 / 4 / 1969$ & 37 & 2 & 0 \\
$9 / 5 / 1969$ & 38 & 1 & 0
\end{tabular}

Figure 3 below shows the dollar account of the EEA without the window dressed values (Figure 4 is the raw data). Figure 3 shows smoother data closer to the true reserve position of the Bank of England.

Figure 3 - dollar reserve data 1965-1970 (without window dressing)

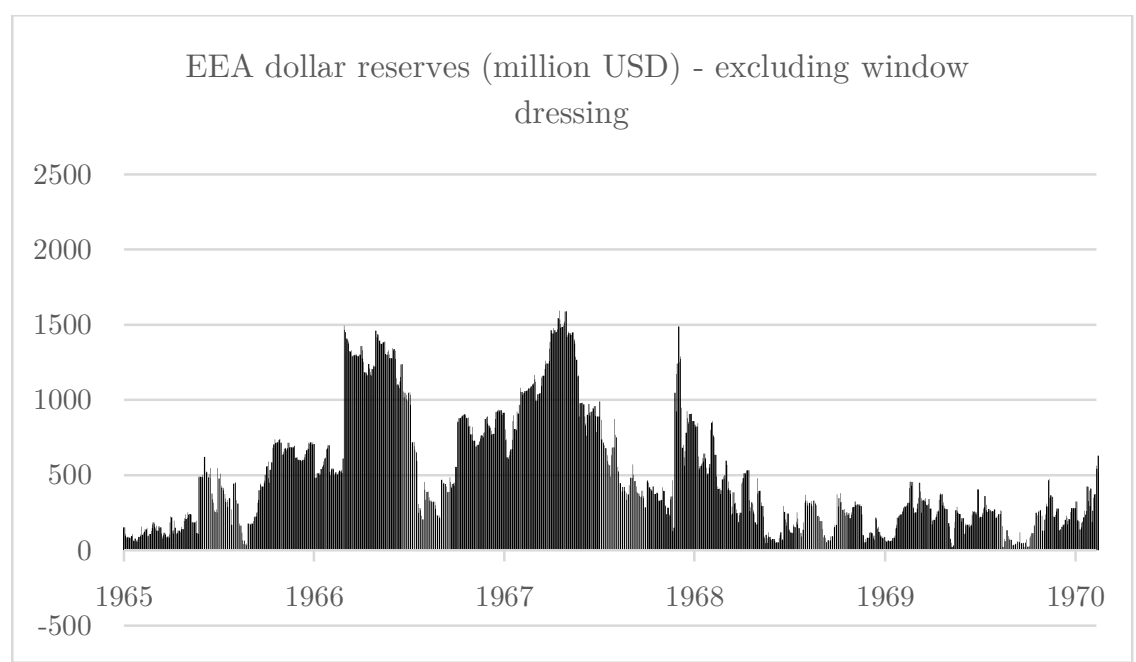


Figure 4 - dollar reserve data 1965-1970 (with window dressing, raw data)

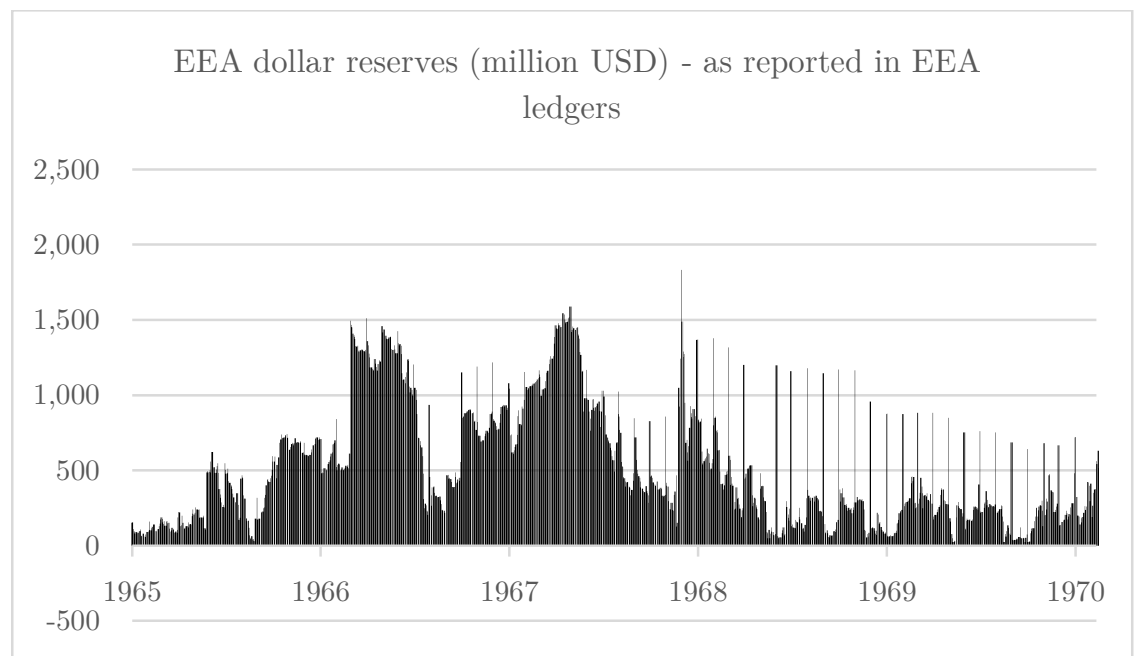

\section{Data availability}

The data of this project is available on the repository openICPSR at the following address: https://www.openicpsr.org/openicpsr/project/130681/version/V1/view. One file offers the British and Swiss daily data and another the monthly French data. It can be used for analysis and further study.

\section{Conclusion}

This paper offers new daily data on central bank reserves during the Bretton Woods period. They are released here for other researchers to use in further analysis and research. The paper also offers processing of the data of the EEA to remove window dressing operation, making the data smoother for further analysis. 


\section{References}

Avaro, Maylis. 2020a. 'Essays in Monetary History'. IHEID PhD disseration 03-2020. The Graduate Institute of International Studies.

. 2020b. 'Zombie International Currency: The Pound Sterling 1945-1973'. IHEID Working Paper 03-2020. Economics Section, The Graduate Institute of International Studies. https://econpapers.repec.org/paper/giigiihei/heidwp032020.htm.

Bank of England. 1968. 'The Exchange Equalisation Account: Its Origins and Development'. Bank of England Quarterly Bulletin, December, 377-90.

Chiţu, Livia, Barry Eichengreen, and Arnaud Mehl. 2014. 'When Did the Dollar Overtake Sterling as the Leading International Currency? Evidence from the Bond Markets'. Journal of Development Economics, Special Issue: Imbalances in Economic Development, 111 (November): 225-45. https://doi.org/10.1016/j.jdeveco.2013.09.008.

Eichengreen, Barry, and Marc Flandreau. 2009. 'The Rise and Fall of the Dollar (or When Did the Dollar Replace Sterling as the Leading Reserve Currency?)'. European Review of Economic History 13 (3): 377-411. https://doi.org/10.1017/S1361491609990153.

Howson, Susan. 1980. Sterling's Managed Float: The Operations of the Exchange Equalisation Account, 1932-39. International Finance Section, Department of Economics, Princeton University. https://www.princeton.edu/ ies/IES_Studies/S46.pdf.

Monnet, Eric, and Damien Puy. 2020. 'Do Old Habits Die Hard? Central Banks and the Bretton Woods Gold Puzzle'. Journal of International Economics 127 (November): 103394. https://doi.org/10.1016/j.jinteco.2020.103394.

Naef, Alain. 2019. Sterling and the Stability of the International Monetary System, 1944-1971. Cambridge: University of Cambridge. https://doi.org/10.17863/CAM.32540. 
— 2020. 'Dirty Float or Clean Intervention? The Bank of England in the Foreign Exchange Market'. European Review of Economic History. https://doi.org/10.1093/ereh/heaa011.

Schenk, Catherine. 2010. The Decline of Sterling: Managing the Retreat of an International Currency, 1945-1992. Cambridge University Press.

. 2011. 'The Retirement of Sterling as a Reserve Currency after 1945: Lessons for the US Dollar?' World Financial Review, May. http://www.worldfinancialreview.com/. 


\section{Appendix}

\section{A) Data sources overview}

Figure A1 - Bank of England data

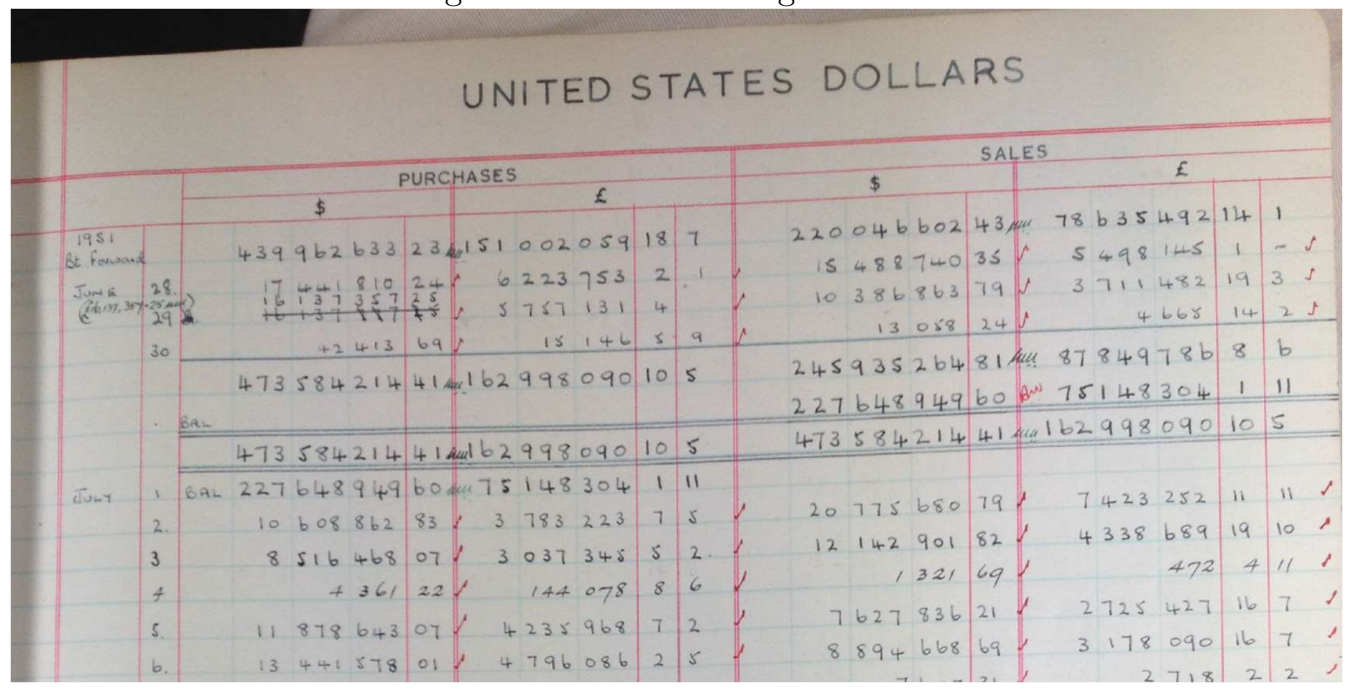

Figure A2 - Bank of France

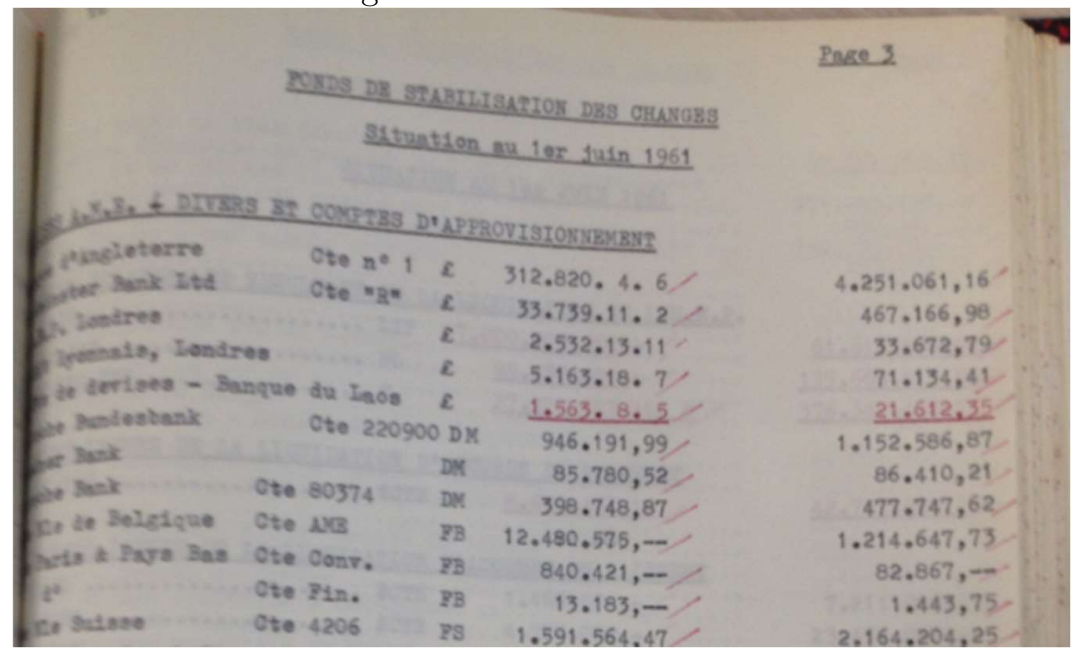


Figure A3 -Swiss National Bank

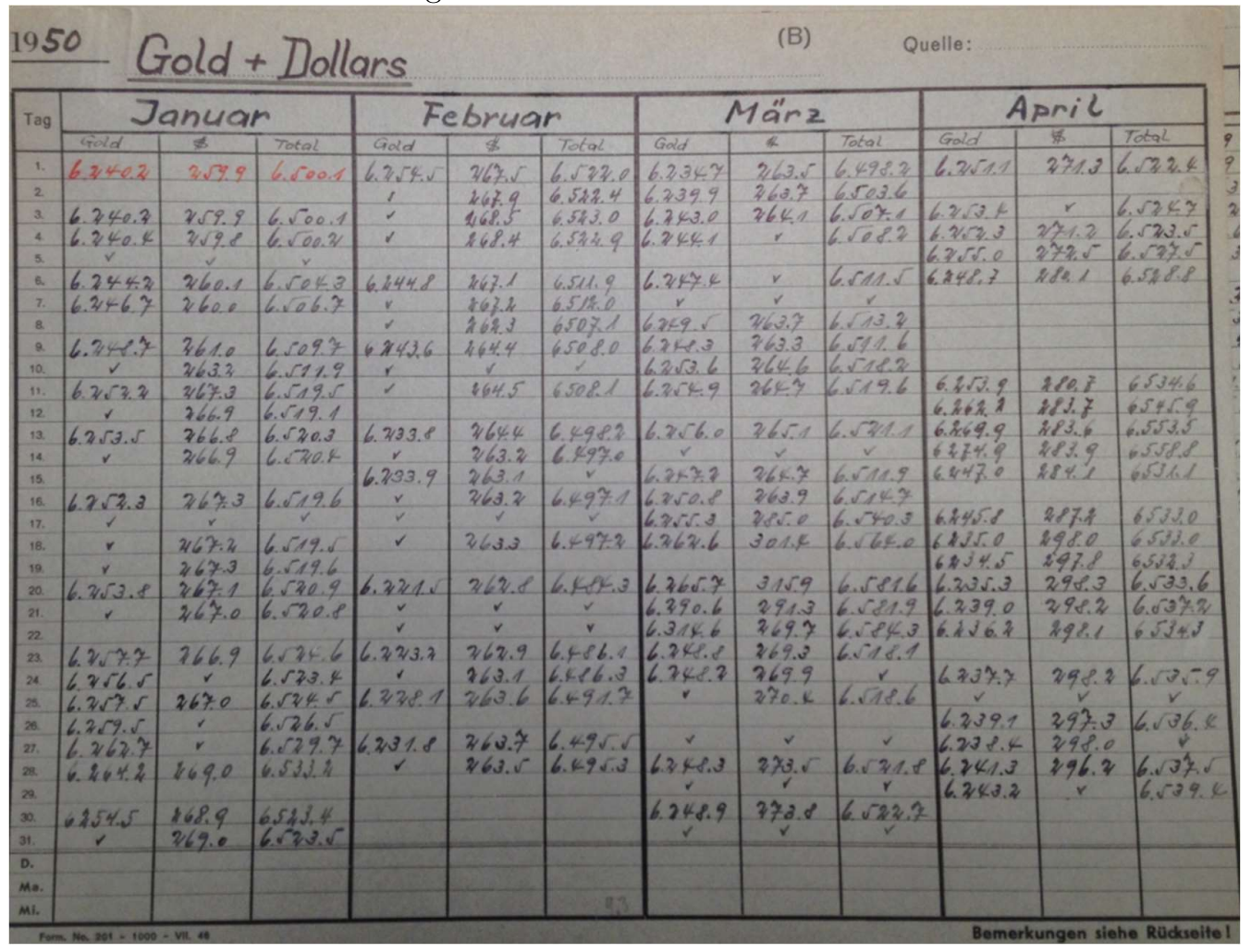




\section{B) Bank of France data labels}

Avances de la Banque de France

Or Banque de France - or sous dossier

Or à l'affinage

Or acheté au cours du marché libre

Or en dépôt à l'Administration des Monnaies

Réservé à acheter par le trésor

Or Banque d'Angleterre Cte Spécial Lingots

Or Banque d'Angleterre Cte Spécial Monnaie

Or Banque d'Angleterre Cte "T" Lingots

Or Banque d'Angleterre Cte "T" Monnaie

Bank of Canada-Ottawa Or sous dossier

Federal Reserve Bank Or sous dossier

IMF ( - Paris)

Or a la disposition de la banque de l'Indochine - New York

B.R.I. Or sous dossier Londres (merged with livraison Bale)

B.R.I. Or sous dossier - Berne

B.R.I. Or sous dossier - New York

Fonds Monétaire International (New York)

Banque Nationale Suisse - Monnaies / or sous dossier

Or en depot - Comptoir Lyon Alemand

Or versé par la Bque Nle de la Répub. Fédér. Popul. de Yougoslavie, en application de l'accord franc-yougoslave du 28 mai 1954 en attente d'affectation

Or achete a la clientele (au cours du marche libre-circ. 86.559 du 11 juillet 1958)

Sous dossier à Osaka - Japon

Banque d'Etat du Maroc - Tanger

Or à la disposition de Dreyfus Bale - Loco Paris

Or sous dossier De Nederlansche Bank - Amsterdam

Banque de France - son prêt en or

opérations à option or à rétrocéder $\$$ sur options réciproques

Or a regulariser sur echange

Engagements contractes envers le F.M.I. au titre des sommes tirees sur la tranche or du quotea francais et non remboursees

$\$$ à acheter c/or sur options réciproques

Banque d'Angleterre Cte ${ }^{\circ} 1$

Banque d'Angleterre pacements Cte $n^{\circ} 1$

Banque d'Angleterre Cte $\mathrm{n}^{\circ} 3$

Banque d'Angleterre Cte X

Banque d'Angleterre Cte spécial

Westminster Bank Cte "R" 
Westminster Bank Cte "V"

British Continental BK.

British French Bank

G.N.E.P.

C.I.C.

Crédit Lyonnais

C.F.A.T.

Société Générale

Sterling chez Co Frse des Pétroles

Devises Union Europeenne de Paiements

Devises UEP credit spécial

Reserves a acheter par le tresor amort 1952

Federal reserve Bank Cte "T"

Federal reserve Bank Cte "T" Placements

Federal reserve Bank Cte "V"

Federal reserve Bank Cte "D"

French american banking " $\mathrm{T}$ "

J.P. Morgan \& Co Inc. Cte "T"

J.P. Morgan \& Co Inc. Cte "V"

Bankers Trust co

Chemical Bank Trust

Central Hanover Bank

The Chase Bank

The Chase Bank Aux. \$

The Chase Bank Ex. Acc.

National City Bank

Guaranty Trust Co

Lazard Frères

J.H SCHROEDER

Bank of America Cash account

Bank of America San Franscico

$\$$ a vue Cte Spécial attente B.R.I.

$\$$ en dépôt à la B.R.I.

Devises réservées à

Supreme Commando A1 Powers SCAP

$\$$ à la disposition de l'A.T.I.C.

Banques américaines - ctes de dépôt

USA chez Fed Reserve Bk dépôt en devises

Devises à la disposition de tiers

Various aggregated line items 
Messageries Maritimes-dépôt de devises

Compagnie Wacum française dépôt de devises

Banque centrale Equateur

FED accounts

FED ratio FRF USD

Various ratio FRF USD

Total ratio FRF USD

Banque du Japon Cte Nouv.

Banque du Japon Cte Anc. 